\title{
Transcending National Boundaries: Hilda Taba and the "New Social Studies" in Australia, 1969 to 1981
}

\author{
LINDSAY J. PARRY
}

$\mathbf{T}$ he influence of curricular and pedagogical practices espoused by social studies educators in the United States frequently transcends national boundaries. Indeed, accounts of curriculum development and reform efforts in the diverse societies of Australia (Parry 1998), Canada (Fowler 1997), Japan (Nagai 1979), New Zealand (Openshaw 1992; Barr 1993), Nigeria (Onyabe 1979; Ukpokodu and Osunde 1996), and Thailand (Meesing 1979) trace the adoption of many influential curricular and pedagogical practices back to prominent educators from the United States.

Also important, those accounts demonstrate that curricular and pedagogical practices are not simply adopted without undergoing varying degrees of transformation. As the practices are transplanted across societies, they are continually shaped and reshaped by curriculum developers and contextual influences, including national and local cultures, educational and curriculum structures, and pedagogical practices (Lagemann 1983; Goodson 1992). Ivor

LINDSAY J. PARRY teaches social studies curriculum as a member of the Faculty of Education at Griffin University in Brisbane, Queensland, Australia.
Goodson $(1992,23)$ made this point well when he wrote:

[T] he subject-based curriculum might be an aspect of globalization and modernization but we need to know precisely how this global pattern interacts and collides with more local/national cultures and structures... We need detailed local and historical studies of how common school subject labeis override different patterns of knowledge formation and institutionalized practice.

From Goodson's perspective, the historical analysis and interpretation of the influence of curricular and pedagogical practices across national boundaries will enhance our understanding of the complex interplay between social studies and divergent cultures, structures, and practices. Such analyses and interpretations point toward the patterns and structures of national and/or state educational and curricular policy making. They point toward the role, aspirations, and experiences of curriculum workers and toward the processes of educational and curricular policy making. They point toward contexts and constraints, tradition and change, and continuities and discontinuities in educational and curricular policy making. They also point to teacher endorsement of and resistance to educational and curricular policies. Taken together, these historical analyses and interpretations ought to establish the evolutionary nature of curriculum development, or what Goodson $(1984,27)$ called the "gradual and continuous nature of curriculum change."

In this article, I examine the transplanting of curricular and pedagogical practices from the United States to the state educational system of Queensland (one of eight states and territories in Australia) from 1969 to 1981. Over that twelve-year period, curriculum workers adopted curricular and pedagogical practices associated with the theoretical perspectives of Hilda Taba and the discipline-based developments of the "new social studies" movement in the United States throughout the 1960s. In examining these relationships, I have focused on the processes and products of transplanting practices from the United States into Queensland, and the role of curriculum workers and contextual influences on those processes and their products. I have considered the official efforts at the state level and not examined or evaluated the impact of the "new social studies" at the local level. That is, I examined the conceptualization and development of the "official state curriculum" and not the "actual curriculum" as experienced by teachers and 
their students in schools and classrooms. Nevertheless, in a concluding discussion, I discuss the perceptions of curriculum workers and other educators on the impact of the "new social studies" in state elementary schools, as gleaned from their participation in inservice programs for teachers.

My hope is that my article contributes to a "thickened history" of curriculum development and reform in social studies. Such a history, according to Ellen Condliffe Lagemann (1983, 251), "takes full account, not simply of trends and forces, but of particular events and places and singular persons, including the thoughts, words and deeds, which are the conclusion to their beliefs and values." In endorsing this perspective, oral history methods have been employed, along with the more traditional analyses of documentary sources (minutes of meetings and policy statements). Both methods afford valuable insights into the deliberations, decisions, and actions of curriculum workers. But oral history methods provide individual curriculum workers with a "voice" through which they can recall their contributions to this episode of curriculum development and reform and reflect on the specific influence of curricular and pedagogical practices espoused by Hilda Taba and other prominent educators from the United States. Their "voices" provide contrasting perspectives on that particular episode of curriculum development and reform in social studies and offer critical commentaries on the adoption of those curricular and pedagogical practices. Where appropriate, the perspectives and commentaries are corroborated by official departmental documents and reports. I hope that this "thickened" history contributes further to our understanding of the transnational character of social studies and its manifestations within differing social, cultural, and educational contexts.

\section{Curriculum Workers and Contextual Influences}

My account begins with a descriptive-analytic overview of the involve- ment of the curriculum workers and the contextual influences that impacted upon their work. In early 1969, eight curriculum workers (Adams, Bauer, Clarke, Graham, Hughes, James, Taksa, and Wright) met for the first time in the central offices of the Department of Education, Queensland, to begin work on the development of a new syllabus in social studies for state elementary schools.

They were to be engaged in a "topdown" process of curriculum development in which a centralized syllabus would be produced and disseminated to schools and teachers. Like other departmental curriculum developers at the time, the social studies team operated under state legislative controls pursuant to Section 24 of the Education Act 1964-1974 and departmental procedures under the supervision of the Inspectorate and the Director of Primary Education, the Director-General of Education, and the Minister for Education. In breaking with past ad hoc institutional procedures, the social studies team was not to be disbanded after their formal syllabus development work had been completed. Instead, they were to conduct in-service programs for teachers across the state and undertake a continuous review of social studies. Curriculum workers were selected by the Director of Primary Education and were purported to be representative of the inspectorial, administrative, and teaching staff of the Department of Education and lecturing staff of teachers colleges.

The curriculum workers had contrasting backgrounds and professional experiences and held different positions within and outside of the department. They also approached the development of the new social studies syllabus from contrasting positions and perspectives.

Gordon Wright was an articulate, vibrant, and persuasive senior project officer within the Department of Education and had academic interests in sociology and the teaching of thinking skills and processes. He was responsible for the organizational and managerial aspects of syllabus development and wrote most of the philosophical and pedagogical statements in the syllabus.
Wright was the driving force behind the adoption of many new and significant theoretical approaches in the syllabus and was, to use his words, "hot-to-trot" (Wright 1993). In consultation with other curriculum workers, he planned the in-service program that supported the adoption of the new syllabus in state elementary schools.

Gary Hughes, a historian from a Brisbane teachers college, was actively sought to promote the inclusion of historical content and thinking processes in the syllabus. He wanted to ensure that the new syllabus had academic integrity and that it would contribute ultimately to the professional development of teachers.

And the remaining self-named "practical people" (including the chairperson of the team, Gerry Clarke) were school inspectors and principals who brought an intimate knowledge and understanding of schools, classrooms, and teachers to their deliberations. They scrutinized the philosophical and pedagogical principles espoused in the syllabus with a view to their actual adoption in real classrooms and with real children. They shared a concern that pupils "came out with a certain amount of knowledge about what was going on around them" (Graham 1993). The practical people were primarily concerned with the development of teaching materials and resources to complement the syllabus and its adoption in state elementary schools.

By December 1970, the social studies team completed the first of three core syllabus documents. It was entitled $S y l$ labus in Social Studies for Primary Schools, Book 1: Grades 1 and 2 (Department of Education, Queensland 1970a). It was followed shortly by the Syllabus in Social Studies for Primary Schools, Book 2: Grades 3, 4 and 5 (Department of Education, Queensland 1971a) and Syllabus in Social Studies for Primary Schools, Book 3: Grades 6 and 7 (Department of Education, Queensland 1971b). The detailed and comprehensive statements were supported by two teachers' guides: A Guide for the Social Studies Teacher: Book 1, Grades 1 and 2 (Department of Education, 
Queensland 1970b) and A Guide for the Social Studies Teacher: Book 2, Grades 3 To 7 (Department of Education, Queensland 1972). The guides espoused and explained further the philosophical and pedagogical principles of the new social studies syllabus.

The team's work arose partly because of widespread discontent with the $S y l$ labus or Course of Study (Department of Education, Queensland 1952) that was introduced into Queensland schools in 1952 and revised slightly in 1964 (Department of Education, Queensland 1964). In fact, senior departmental officials were calling for major changes to the syllabus shortly after its revision in 1964. In his annual report for the year 1965, G. K. D. Murphy (then the Director General of Education) alluded to those changes by signaling that the elementary school curriculum ought to respond to "modern advances in knowledge and the changing demands of today's world" (Department of Education, Queensland 1965,8 ). He was also concerned about "the way in which children learn" (Department of Education, Queensland 1965, 8).

Those emerging strategic directions shaped the work of the social studies team, just as they influenced the development of syllabuses for art (1972), health and physical education (1972), language arts (1974-5), music (1974), and mathematics (1974-76). All the new syllabuses called for unprecedented changes to the curricular and pedagogical practices employed in state elementary schools.

In social studies, the changes put forward by the team represented a clear rejection of the goals and curricular and pedagogical practices of the 1952 syllabus, which had defined social studies as a loose correlation of geography, history, and civics. Informed by the philosophical and pedagogical approaches of the child-centered and progressive educational thinking of the 1930s (Parry 1998), it had stressed the development of citizenship education through the acquisition of "right" attitudes and "good" social behavior (Parry 1998). According to Graham (1993), it was "just a bare-bones sort of thing" that emphasized "the learning and regurgitation of facts." It was, continued Graham (1993), "well and truly out of date" and "pitiful in lots of ways."

Other influences from further afield also shaped the curriculum development activities of the team. Most notable among those were the innovative curricular and pedagogical practices associated with the widespread movement of sequence, multimedia materials, and the infusion of social sciences in curriculum designs.

It was not until the late 1960 s that curriculum materials associated with the Anthropology Curriculum Study Project, the Harvard Project, and the Fenton/Good Project at Carnegie-Mellon began to appear. By 1972, the bulk of the "new social studies" materials

\section{More than fifty new social studies curriculum projects, supported by scholarly societies and congressional funding, were undertaken by university professors and tested in school districts throughout the United States.}

curriculum development and reform called the "new social studies," which had its origins in the United States in the 1960s. That movement had been ushered in by the Soviet launching of Sputnik in October 1957 and was characterized by large-scale, discipline-based curriculum projects that emphasized the structure of the social sciences and modes of inquiry adopted by social scientists.

More than fifty new social studies curriculum projects, supported by scholarly societies and congressional funding, were undertaken by university professors and tested in school districts throughout the United States (Haas 1977; Hertzberg 1981; Fenton 1991). The projects employed a "top-down" model of curriculum development in which project materials were researched, developed, disseminated, and finally adopted in schools and classrooms (Fenton 1991). Their objectives were drawn overwhelmingly from the knowledge, structure, and modes of inquiry of history and social science disciplines rather than the child or society (Bruner 1960; Goodlad 1966; Fenton 1966a, 1966b). They employed discovery methods of teaching that encouraged students to use facts, concepts, and generalizations to generate new knowledge (Fenton 1966a, 1966b). They experimented with scope and were published (Hertzberg 1981). By the mid 1970s, "the movement was dead and the materials were gathering dust on bookroom shelves" (Fenton 1991, 85).

Many of the projects, according to Hertzberg $(1989,98)$, "used, or rather discovered or perhaps reinvented all unwittingly, many of the methods of teaching and learning that humanistic progressive educators had created and popularized." Humanistic progressivism, as Hertzberg $(1989,98)$ pointed out, "seeks to nurture the development of the individual while at the same time encouraging students to participate actively as citizens in a democratic society." "It has the potential to meet the challenge of our times," added Hertzberg $(1989,98)$, by providing "a commitment to change and to the study of change as a major theme in the curriculum." This "reinvention" of humanistic progressivism by the new social studies educators also represented, as Rossi (1992, 42) acknowledged, "a clear rejection of the rationale of the 1916 NEA Committee on Social Studies and the social efficiency school of thought." It mirrored earlier calls "for a curriculum that was empirical and scholarly and based on the academic disciplines. The humanist school had reasserted its ascendancy" (Rossi 1992, 42).

The implications of those curricular and pedagogical practices were imme- 
diately obvious to those working on the new curriculum in Queensland. They had been closely following post-Sputnik curriculum development and reform efforts in the United States. Some of their immediate supervisors had visited the United States to "look at new trends and developments, and to come back and put them into our scheme of things here" (Graham 1993). They also learned of those trends and developments from international visitors such as Jack Fraenkel (at that time, a close associate of Hilda Taba), correspondence, sharing of draft materials, and the educational press.

Writings by Jarolimek (1968), Michaelis (1968), Taba (Fraenkel et al. 1969) and others from the United States were particularly influential. Their theoretical perspectives were an educational awakening for many of the Queensland developers. For most. the writings resulted in a significant reassessment of their preconceptions of social studies and its role in elementary schooling. For instance, Graham (1993) vividly recalls that

Without any warning, we were just summoned into the Treasury Building [in the early 1970s, the central offices of the Department of Education were located in The Treasury Building, an architectural masterpiece in a neo-Gothic style that was formerly occupied by the State Treasury] and told that a new syllabus was about to be made. We were to sit down and do our reading and prepare ourselves for this work. We had books all around us: Jarolimek, Michaelis, Taba, and a whole lot of other books. We sat around and read, and read, and read, and wondered what had hit us. It was all strange. It was completely new to us. We were brought up on the old school of thinking for social studies. We wondered how we would manage, especially in the early stages. Once we did our reading, we just sat down and began to work on the new syllabus.

Graham's experiences were not unique. At first, Clarke and Taksa also found the theoretical perspectives in the post-Sputnik educational discourse to be somewhat daunting. For others, the perspectives and their presentation in expensively produced publications were "simply irresistible." As Hughes (1993) commented,
These developments were certainly an awakening, a renaissance to us. They [prominent educators from the United States] had clearly approached curriculum planning in great depth and their materials looked very enticing. There is no doubt that we were much influenced by them. Their presentation was attractive and we'd never seen anything like that. It was obviously the product of a lot of money. The education scene in the United States was certainly given enormous capital sums, the likes of which we had never seen. So, these materials had a great deal of appeal.

The "new social studies" movement from the United States had transcended national boundaries and influenced curriculum workers in Queensland. That influence is readily acknowledged in departmental reports and syllabus documents. "It seems clear by now," one report states (Department of Education, Queensland 1968a, 3), "that the social studies are indeed in the midst of a genuine revolution." The report continues:

Educational critics have long complained that many social studies curriculums are obsolete and that most have remained unchanged for decades. The traditional curriculum disregards the non-Western world, ignores for the most part the disciplines of the behavioral sciences, over-emphasizes factual content, and contributes little to the cognitive development of pupils or their ability to analyze and deal with conflicts in values. (Department of Education, Queensland 1968a, 3)

It is perhaps not surprising that the influences from the United States increasingly influenced the educational thinking in Queensland. Multinational companies based in the United States were influencing the Australian economy and society, especially with their mining and pastoral interests in Queensland and persuasive infiltration of the mass media. Both societies shared mutual defense interests in Asia, with Australia's ten-year involvement in the Vietnam war, from 1962 to 1972, representing the most critical articulation of those interests and policies. The war had profound consequences for both societies but never seriously threatened the Australia-United States alliance popularized by the political catch-cry of the era, "All the way with LBJ" (Lyndon B.
Johnson). Indeed, it would be difficult to identify an aspect of Australian society that has not been influenced in some way by the importing of American social, cultural, and political ideals throughout this century (Cremin 1988).

Given the apparent significance of these and other influences from the United States, the question arises: How were curricular and pedagogical practices transplanted by curriculum workers in Queensland from 1969 to 1981 , and what contextual influences shaped the processes and their products?

\section{Transplanting Curricular and Pedagogical Practices in Queensland}

The influence of theoretical perspectives espoused by prominent educators from the United States on the curriculum workers in Queensland varied considerably. Some perspectives informed the development of goals and purposes of social studies. Other perspectives informed the organization and sequencing of content, and the selection of pedagogical practices.

In reconceptualizing the goals and purposes of social studies, the Queensland team drew extensively on the theoretical perspectives of Jarolimek (1968). They endorsed Jarolimek's view that "scholarship" rather than "citizenship education" was the proper goal of social studies. That meant abandoning the earlier emphasis on the preparation of "good" citizens and the inculcation of the values of obedience, loyalty, and civic pride. In its place, the new syllabus focused on the development of the individual and stressed both cognitive and affective objectives, with the preparation for "active participation in the life of the community" being but one concern among others.

The curriculum developers also adopted a broadened, more people-oriented perspective on social studies. For support, they cited Jarolimek $(1968,1)$, who had stated:

The basic and fundamental concern of social studies education is people-people as they work together in societies, form governments, provide for their material and psychological needs; people 
as they love and hate one another individually and collectively; and people as they make use of the resources of this planet they call their home. In short, everything about man [sic] and his relationships with other men and with his physical and social environments is the concern of social studies education.

Jarolimek's influence can also be traced to the adoption of an experimental approach in which teachers were given increased autonomy in their classrooms. Once again, the syllabus quoted Jarolimek (1968, 441):

The greatest hope for improved social studies instruction lies in imaginative, creative, research-oriented teaching, and this can only occur when teachers are given a measure of freedom in their teaching. The school systems that place a premium on the spark of imagination that leads to new and better ways of teaching are likely to be the ones that will have the most to offer the boys and girls of today who will become the men and women of tomorrow.

In endorsing that view, curriculum workers also tried to produce "new and better ways of teaching" by drawing on the theoretical and curriculum development work in the early 1960s of the late Hilda Taba and her associates (Fraenkel, McNaughton, Wallen, and Durkin 1969) from San Francisco State University (at that time, San Francisco State College). Taba and the project team worked collaboratively and consistently with classroom teachers in Contra Costa County (near San Francisco, California) for an intense period of four years to develop a series of instructional guides for social studies. They emphasized the development of cognitive processes in children in the elementary grades (Fraenkel et al. 1969; Isham 1982).

The Taba Social Studies Curriculum was published by Addison-Wesley as a textbook series with accompanying guides for teachers in the late 1960 s and acclaimed as "one of the most respected and influential curriculum projects that emerged during the new social studies reform movement" (Banks 1985, 44). Taba herself was to become "one of the leading figures in the new social studies movement" (Fraenkel 1992, 172). The influence of Taba's project is readily acknowledged in the introductory pages of the guide for years 1 and 2. It states:

The construction of a curriculum which is sympathetic both to teacher-selection of content and to the need to achieve common objectives can prove to be quite a challenge. Fortunately, over recent years, much research has been undertaken with respect to curriculum planning and in this regard, Social Studies in the primary school has been well served. The United States Office of Education has been to the fore in sponsoring a number of applied research projects, e.g. the Contra Costa (California) scheme, which also provided this present curriculum with a useful theoretical framework. An outstanding feature of the Contra Costa project has been its ten-year period of development and evaluation involving hundreds of practicing teachers, academics and advisers from many sections of the community. (Department of Education, Queensland 1970b, 5)

It referred explicitly to Taba's major work, which had been issued to all state elementary schools prior to the release of the new syllabus:

Queensland teachers will be conversant with the premises, rationale and development of this Social Studies program as outlined in Hilda Taba's Teachers' Handbook for Elementary Social Studies. (Department of Education 1970b, 5)

And, a book review in Quest (Department of Education, Queensland 1968b, 60-61) proclaims that the handbook "describes the rationale for a new approach to a social studies curriculum and to the teaching strategies required." It is seen as

An important text which heralds the arrival of "social science" teaching in elementary schools. However, it pre-supposes some knowledge of the disciplines (in social science) . . . together with a good theoretical grounding in education.

\section{Exemplary Approaches}

Among other things, Taba and her colleagues outlined the innovative and exemplary approaches of the "spiral curriculum" and "inductive teaching" in the handbook. Both approaches were popularized in the United States and began to influence the activities of the Queensland curriculum workers. By the time their work was completed, the new
Taba-based approaches stood in sharp contrast to the existing curricular and pedagogical practices employed by teachers. Both the approaches and their adoption into the Queensland context are discussed in the following sections.

\section{The Spiral Curriculum}

The "spiral curriculum" is a theoretical approach designed to structure and sequence content as concepts rather than as isolated and unrelated facts. In this curriculum, concepts appear at each successive year level in a spiral fashion that expands outward. Children revisit the concepts at increasing levels of sophistication and complexity and at varying degrees of abstraction and generality. The spiral curriculum incorporates the eleven key concepts of causality, conflict, cooperation, cultural change, differences, interdependence, modification, power, societal control, tradition, and values. They were selected for their power to organize and synthesize large amounts of information (Fraenkel et al. 1969; Fraenkel 1992). In the arrangement of the concepts, Years 1 through 4 respectively deal with people in families, neighborhoods, communities, and states. Year 5 is concerned with the study of American society and emphasizes the contributions of various subcultures. Years 6 and 7 consider a separate culture outside the United States.

In drawing on Taba's work, the Queensland curriculum developers advocated the adoption of a spiral curriculum based on key concepts for similar reasons. They argued that certain concepts could be "grasped with varying degrees of understanding according to the abilities of the children" and that these would be "presented in increasing degrees of abstraction in successive grades" (Department of Education, Queensland 1970, i). They recognized that children become able to deal increasingly with broader and more abstract content with chronological age. Therefore, "many main ideas (generalizations), concepts and skills are continually re-introduced in succeeding units, each time at greater depth and breadth" (Department of Education, Queensland 
1971, iii). For instance, year 1 deals with concepts and generalizations taken from experiences that children have close at hand, whereas in year 7 , the concepts and generalizations are more remote and abstract.

Although they endorsed these sentiments, the curriculum workers did not adopt the eleven key concepts from Taba's curriculum. Instead, they decid- the future." That represented a significant departure from Taba's work and an even more pronounced departure from the 1952 syllabus. In terms of the latter, it meant abandoning the existing compartmentalized, continent-by-continent, country-by-country, state-by-state approach to content organization. The consensus was that that pattern had failed to emphasize general patterns,

\section{The curriculum developers in Australia decided against adopting the eleven key concepts from Taba's curriculum. Instead, they chose to identify their own key concepts.}

ed to identify their own key concepts. Graham (1993) described how this task was approached:

We just talked about things. We started off with how Taba constructed her syllabus. We tried to develop some key concepts, basic concepts. Starting there and just working down through the syllabus. We just kept working away at it. After we got through the syllabus, we actually sat down and wrote out units and resources to hand out to schools to show them how to develop their lessons and so on.

The selection and wording of the concepts drawn from the social science disciplines generated a great deal of debate and discussion. As Adams (1993) succinctly stated, "We were talking about concepts ad nauseam. We used to have terrific arguments about what a concept was." It was a long and protracted process that resulted in the formulation of the seven key concepts of needs, groups, rules, change, resources, interdependence, and culture. They also reworked the themes for the seven-year levels. Year 1 became "the individual in a changing environment;" year 2, "groups in an expanding community;" year 3, "people in differing environments;" year 4, "how our way of life developed;" year 5, "meeting the needs of society;" year 6, "the development of various societies;" and year 7, "understanding the present in order to plan for problems, and universal understandings. It was also deemed unsuited to the learning styles of children. Additionally, the changes meant extending the traditional base of geography, history, and civics to include the emerging social science disciplines of anthropology, economics, and sociology. As James (1993) extrapolated,

We didn't just take the organization of concepts and the structure that Taba had developed. We didn't just Australianize it. We took the idea of key concepts and generalizations but developed our own totally. We started from the basic things that we wanted to make sure were included: history, geography, sociology, anthropology, and economics. What are the key concepts there? How do they relate? How do we put them together? What key concepts can we make? So, it wasn't just a case of taking all the work that Taba had done.

In selecting content to support the development of the concepts, the curriculum team engaged in a dual process of selecting and integrating "traditional" and "new" forms of suggested content. Some traditional forms of content were reinterpreted or brought forward in their own right and even placed in the same year levels as in the 1952 syllabus. For example, children continued to study Eskimos and how other peoples live in different climatic regions of the world in year 3, early European exploration of
Australia in year 4, and government in year 7 .

The development team also made major additions and deleted specific forms of suggested content. Studies of the Asian and Pacific regions were introduced. British and European history and geography were investigated, but no longer for their own sake-their influences on the settlement of Australia and the nature of Australian society now were paramount. Australian society and multiculturalism were emphasized. Contemporary social and environmental issues, such as the impact of people on the natural environment and the problems of urban communities, were stressed. Studies of the many functions and processes of contemporary society, including government, industry, transport, and public services, were added. The new areas of content represented significant departures from the traditional selections of content in the 1952 syllabus and reflected social and cultural changes occurring within Australian society and our changing relations within the Asian and Pacific region.

Further, the curriculum workers recognized "that individuals had different goals, values and expectations" and explored "how you could get kids used to change and how we could do something about predicting change or initiating change" (Adams 1993). For as Hughes (1993) succinctly said, "This was 1970-wars, communism, demonstrations, American Indians, Australian Aborigines-we were looking for a better world." In looking for a better world, the curriculum team challenged existing notions of content and knowledge bases, their organization within the syllabus, and their relevance and application to contemporary Australian society within a changing Asian and Pacific region.

\section{Inductive Thinking}

The developers of the new curriculum also drew on the "inductive teaching strategies" advanced by Taba. The strategies are embedded in cognitive processes and employ a variety of precise questioning techniques. In this ped- 
agogical approach, teachers are required to use a number of inductive teaching strategies specified by Taba to promote the development of concepts, analytical skills, and thinking processes, but they exercise considerable freedom in the selection of content. The inductive theory of Taba represents a theoretically well-informed and innovative approach to the teaching of social studies, but as Hertzberg $(1989,96)$ pointed out, "this strain of humanistic progressivism did not save the new social studies from the fascination with process that began to drain it of content."

In Queensland, the curriculum workers similarly realized that the acquisition of knowledge involves the process of inquiry and not merely the acceptance of a static body of facts. They recognized the importance of thinking processes and, for the first time, employed the notion that "thinking" is a process that can be learned. That contrasted strongly with the traditional rote-learning methods advocated in the 1952 syllabus. James $(1993,5)$ saw that "revolutionary" approach to teaching and learning in the new syllabus as prescriptive. He stated:

It is interesting that the policy was very, very intrusive on teaching approaches. The new syllabus didn't leave it open to just any sort of teaching. The deductive, stand up and deliver "chalk and talk" as the one and only method following a textbook from beginning to end, just wasn't on with that syllabus. The policy was, "You will take an inductive approach to teaching!"

To support this approach, the curriculum workers replaced the single department-issued texts for each year level that accompanied the 1952 syllabus with commercially produced books as part of a "mini-library" in classrooms. In 1968, an expenditure of close to a million dollars was approved by State Cabinet (Decision No. 11754, 2 July 1968) to provide state elementary schools with modern textbooks in English, mathematics, and social studies. Social studies was allocated $A \$ 300,000$, slightly less than mathematics (A $\$ 331,000)$, but more than English $(A \$ 281,520)$. Over seventy different resource books together with sets of pictures, slides, sound filmstrips, and simulation games were purchased from publishers for social studies. Most of the texts were from the United States and understandably placed "a strong emphasis on the American rather than Australian setting" (Adams 1993). But as Clarke acknowledged, "We tried to have a lot of resources and it was definitely one of the plusses" (Clarke 1993). He added:

The publishers flooded us with all sorts of beautiful material. Much of it really reflected a better picture of various places throughout the world. They showed how people lived. That was one important thing that was associated with the new syllabus. The emphasis was definitely to get children to arrive at concepts and make deductions. They learnt a lot of things that went on in the world. Another development was the affective side so that children could really understand and have some sort of feeling about the people and how they lived. (Clarke 1993)

The use of inquiry strategies supported by relevant texts was one of the most satisfying aspects of their work. "It made social studies very interesting," said Clarke (1993).

In all, the combined approaches of the spiral curriculum and inductive teaching represented a bold new direction in the teaching of social studies in Queensland. Taba's indirect influence was paramount. To the curriculum workers, Taba "was god-like and we followed her basically" (Graham 1993). But as Graham was quick to caution, "Taba provided the framework and we adapted that to the local needs. . . there is no doubt about that." Hughes endorsed that perspective but saw the process more as an extrapolation exercise. He said, "I found that rather exciting. The difficulty we had was to extrapolate from the Californian scene and put it into place here." That view was endorsed by Wright (1993), who stated:

As I saw it, it was the main theoretical issues of Taba that were most appealing. It was the framework that Taba talked about. It was her emphasis on teaching thinking and her ideas on teaching strategies. They were the things that really won the day for her work. We took those and applied them to the local situation. We

tried to take the best of a few things and integrate them. But, I think Taba was the real basis of the whole thing.

\section{Selling the Syllabus and Mixed Reactions}

The curriculum workers teamed up with other colleagues (Mackle, Stuart, and others) within the Department of Education to support the adoption of the social studies syllabus in Queensland elementary schools. In many respects, that was a more onerous responsibility, because it required selling the philosophy of the syllabus and its new curricular and pedagogical practices to teachers. For as Graham (1993) explained, "It was the hardest syllabus of all to bring into a school because of its radical nature. It was very difficult indeed." Taksa (1993) concurred:

\begin{abstract}
There were big gaps in the knowledge of teachers and there were great problems in introducing the syllabus to them. Teachers were used to a workbook, set content, and teaching for facts. They were not used to teaching for knowledge, thinking, attitudes, and skills. They were also not used to planning units of work. The whole idea of a "flow chart" was unheard of. The knowledge of Taba just wasn't there, except for those who studied at university. So, that was always going to be a problem.
\end{abstract}

The curriculum developers tried selling the syllabus to teachers through a series of workshops, summer schools, and intensive release schools. Workshops adopted a broad-sweep approach over one or two working days in schools. In one particular series of workshops conducted throughout the state, nicknamed the "Grand Tour," the curriculum workers traveled over 12,000 kilometers in eight weeks and "spread the word like the old towncriers" (Hughes 1993). Acting on Wright's advice, the workshops adopted an academic focus that emphasized the theoretical and conceptual underpinnings of the syllabus. As Wright (1993) recalled:

We started out listing ideas from sociology, ideas from anthropology, and ideas from the other social science disciplines. We would have these pie-graphs in which 
you would show what was involved in those disciplines and how they contributed to the central philosophy of social studies. And then, we would look at teaching practices. In hindsight, we expected a lot as it took us a long time to actually come to grips with those teaching practices ourselves. But we expected teachers to grasp these practices up-front.

Summer and intensive release schools during the holidays and school terms covered in the sessicris that you could see the confusion creeping in. It needed a lot of follow up work." (Mackle 1993). Graham (1993) concurred, saying

One of the problems was that the in-service courses were too academic. With due respects to Gordon Wright, they were far too academic. Wright was a terribly knowledgeable fellow. But, he was doing studies at the university in sociology and

\section{Teachers received intensive inservice training for using the new syllabus. Forward-looking teachers responded positively and began to develop their own units, featuring group work and the project method.}

were more successful. "Instead of having just little bits and pieces from here and there," commented Adams, "teachers were saturated for six weeks." They were, observed Adams, "the most successful things that were ever done." He added, "They were the best. The change in those people over that six weeks was unbelievable" (Adams 1993). Eventually, funding for the in-servicing of teachers was withdrawn, and other schoolbased methods were tried.

Teachers reacted differently to the new syllabus and the in-service workshops and schools. "By and large," recalled Clarke (1993), "teachers were quite happy with the syllabus and the inservice programs." As observed by Taksa, those "who were forward looking loved it." In time, many teachers gained the confidence to develop their own units of work and "spent many, many hours doing that" (Wright 1993).

Some teachers, however, experienced difficulty understanding the theoretical perspectives adopted in the new social studies. They were confused by the educational terminology employed in the syllabus and the academic format of the workshops generally compounded their misunderstandings. "There was a lot of confusion," commented Mackle (1993), "because teachers were coming upon a lot of this terminology for the very first time." Additionally, "there was so much the sessions were steeped in sociological theory. You can't just give that to teachers practicing in schools. Most of them were dead scared of the syllabus. They were frightened of it. At seminars, you would hear the remark from the back, "Bullshit." You would hear that all over the hall. "What a lot of bullshit." You could understand their worry about it. Talking about concepts and generalizations would have meant nothing to them, as it did nothing to us when we started working on the syllabus. Just to hit them with that sort of thing was too much. As a result, it took a lot of them a long time to get anywhere with it. I don't think that there were many schools who were really doing it as well as they should have done. But, to go and hit them with lectures on sociology - that ruined the whole thing. In hindsight, I think we could have made a much better job of it.

Graham (1993) believed that a clearer, more practical approach would have helped teachers grapple with the sophisticated educational terminology employed in the syllabus. Wright (1993) did not dispute this and argued that "it was new for them and people were dead scared." He added:

I used to actually run in-service programs with forty, fifty, sixty, seventy teachers where I would actually treat them like a classroom of kids, and actually use a Taba teaching strategy with them such as listing, grouping and labeling. That's probably where many of my colleagues had trouble, because they saw that as being too heavy a move too early, too strong, and too difficult for many teachers. I think for some of them it might have been like speaking another language, particularly where they have come from basicskills, learning-facts type backgrounds. (Wright 1993)

Indeed, Taksa (1993) best summed up the feelings of many teachers when she observed,

Teachers saw it as a completely different approach, a completely radical change. There was antagonism and rejection of the syllabus to a great extent because they felt there was little continuity. Furthermore, teachers were not used to planning together, and this was essential with the spiral curriculum.

When concept development was attempted in classrooms, some teachers did not understand the process. Taksa (1993) explained that as follows:

Our work in classrooms was designed to get children to come up with an inference or a generalization in their own words. They would put the whole lot of them up on the blackboard so that nobody is going to be wrong, but there will be degrees of "rightness." And, we could look at them, compare them, and hypothesize about them.

Taksa (1993) said, however, "That was a foreign world to most teachers as they simply taught the generalizations." She explained:

I would walk into a classroom and a generalization would be written up on the board. You had to show teachers that there was another way to get that. You had to let the children arrive at it themselves. You don't really need that particular wording. But, that syllabus was being policed by an Inspectorate who didn't know anything about it. School Inspectors wanted that result. (Taksa 1993)

For many teachers, group work and the "project method" became the favored approaches to teaching the new social studies. Unfortunately, many of the projects, observed Adams (1993), "had absolutely nothing to do with developing concepts or generalizations, and very little to do with attitudes, values, and feelings. It was just a lot of pictures stuck on to bits of paper." "Teachers," added Adams (1993), "did not understand how to develop concepts and generalizations." Other problems and 
mixed messages began to emerge. For some teachers, thinking processes became paramount, and knowledge was no longer considered important (Hughes 1993). For other teachers, knowledge and factual information retained its importance, but they were puzzled about which specific facts needed to be taught (Taksa 1993; Clarke 1993). Some teachers, according to Clarke (1993), still "wanted the old list of rivers, mountains, and products. They wanted to deal with one country in one grade and another country in another grade."

These and other observations were confirmed, in part, in a study of classroom planning practices conducted by Smith and Funnell (1981). In an interview-based study of five Brisbane primary schools, they concluded that many teachers in those schools had difficulty constructing learning experiences designed to achieve concept development. They noted the possibility that concept development, a central feature of the new syllabus, was being ignored. Reflecting on that finding, Wright (1993) concluded that "teachers picked the eyes out it and took from it what they thought they could understand. They saw it through the glasses of the old and that didn't help a great deal. I think that's where you were getting some mixed messages."

Despite the mixed messages and resistance by some teachers in Queensland, the new social studies syllabus attracted considerable interest from curriculum developers and teachers in other Australian states. "In fact," recalled Stuart (1993), "the new syllabus was the biggest selling document anywhere in Australia in terms of social studies." In many respects, it set the agenda for other curriculum development and reform efforts in social studies across Australia. For as Wright (1993) emphatically stated,

During this time, the states of New South Wales and Victoria were very impressed with what was happening in Queensland. In particular, there was a big purchase of the syllabus by Victorian teachers. In many respects, Queensland was really moving well ahead of most other states. New South Wales had started the ball rolling, but I think we surpassed them and went well beyond that. I think that we were doing some quite significant things and I think leading Australia at that time.

\section{Conclusions}

The influence of the curricular and pedagogical practices espoused by Hilda Taba (and other prominent social studies educators in the United States such as Jarolimek and Michaelis) shaped the activities of a generation of curriculum developers in Queensland from 1969 to 1981. The curriculum workers were basically in awe of Taba's contributions, especially her notions of the spiral curriculum (that was built around concepts and generalizations) and inductive thinking processes (Graham 1993). Both approaches provided the theoretical scaffolding for their new social studies syllabus.

Some educators and curriculum workers contend that these approaches still have educational legitimacy. For Fraenkel (1992, 172), Taba's approaches "are as relevant today as they were in 1967 at the time of Hilda's death." He explained his stand by stating:

Many of Hilda's ideas. . had a considerable influence during the $1960 \mathrm{~s}$ and 1970 s on inquiry-oriented social studies teachers. The focus on multiple objectives, the spiral curriculum, the emphasis on thinking, the use of inductively organized teaching strategies, the development of teaching and learning units organized around concepts and ideas, and the sequencing of learning activities are as important today as they were twenty-five years ago when they first began to be talked about. (Fraenkel 1992, 178)

The new standards are still popular with the curriculum workers who developed and supported the adoption of the new social studies syllabus in Queensland from 1969 to 1981 . Their personal respect and admiration for Hilda Taba and her contributions continue unabated today.

However, Taba's approaches appear to have been less accepted in state elementary schools. They called for major changes in curricular and pedagogical practices, in the selection of content to develop concepts and generalizations, and in curriculum planning processes at the school and classroom levels. Some teachers enthusiastically embraced these new ideals and processes, whereas others floundered because of their reluctance to change or their lack of knowledge and skills. As Taba demonstrated in Contra Costa schools in California, teachers needed to be provided with training and support for these changes to be adopted successfully. Even then, Taba's personal presence and support were critically acclaimed (Isham 1982; Fraenkel 1992).

In Queensland, teachers were introduced to the theoretical perspectives underpinning the syllabus through academically oriented in-service programs throughout the 1970s. Unfortunately, they did not prepare teachers adequately for the challenges to be faced in adopting these approaches in schools and classrooms (Taksa 1993; Wright 1993). In-service programs did not suit their needs, and funding for additional support was not forthcoming. As a result, the adoption of the new social studies was plagued by mixed messages and problems in Queensland classrooms throughout the 1970 s (Wright 1993). By 1981, a new generation of curriculum developers was being recruited to address these deficiencies and problems. Their work was primarily in response to the pragmatic concerns of teachers and was to be seven years in gestation. A "thickened history" of their work and responses to the Taba-based curriculum in Queensland has yet to be told. Such a history would contribute to what Goodson $(1992,5)$ noted earlier as, "the unique evolution of school subjects." He explained that as follows:

Each school subject...must be located within its cultural and political milieu and within its historical context. These milieux and contexts differ very substantially and our insights into school subjects and schooling have a unique significance in each particular country, at each particular time.

"Thickened histories" that account for these different patterns and their manifestations within differing contexts are much needed, and no more so than of the innovative and radical curricular and 
pedagogical practices of the 1970 s and their legacy throughout the 1980 s.

\section{REFERENCES}

Adams, B. 1993. Interview, Brisbane, Australia. 26 August.

Barr, H. 1993. Survival in the South Pacific: The new social studies in New Zealand. The Social Studies 84(4): 325-28.

Banks, J. A. 1985. Teaching strategies for the social studies: Inquiry, valuing, and decision-making (3rd ed). Reading, Mass.: Addison-Wesley.

Bruner, J. S. 1960. The process of education. Cambridge: Harvard University Press.

Clarke, T. 1993. Interview, Brisbane, Australia. 2 November.

Cremin, L. A. 1988. American education: The metropolitan experience, 1876-1980. New York: Harper and Row.

Department of Education, Queensland. 1952. The syllabus or course of instruction in primary and intermediate schools. Brisbane: Government Printer.

- 1964. The syllabus or course of instruction in primary and intermediate schools. Brisbane: Government Printer.

-_ 1965. Annual Report. Brisbane: Government Printer.

1968a. Thinking skills in social studies. mimeo.

$1968 \mathrm{~b}$. Book review of Teachers handbook for elementary social studies. Quest 2(1): 60-61.

Q1970a. Syllabus in social studies for primary schools, book 1 (grades I and 2). Brisbane: Government Printer. 1970b. A guide for the social studies teacher, book 1 (grades I \& 2). Brisbane: Government Printer.

- 1971 a. Syllabus in social studies for primary schools, book 2 (arades 3,4 and 5). Brisbane: Government Printer. 1971 b. Syllabus in social studies for primary schools, book 3 (grades 6 and 7). Brisbane: Government Printer. 1972. A guide for the social studies teacher, book 2 (grades 3 to 7). Brisbane: Government Printer.

Fenton, E. 1966a. Teaching the new social studies in secondary schools: An inductive approach.. New York: Holt, Rinehart and Winston.

1966b. History in the new social studies. Social Education 30(5): 325-28. 1991. Reflections on the "new social studies." The Social Studies, 82(3): 8490.

Fowler, R. (1997). Teaching for enlightened citizenship and social responsibility: A Canadian perspective. In International trends and developments in social studies-Seminar report on the International Assembly of the National Council for the Social Studies, Washington, D.C., November 1996, edited by J. Bron and $\mathrm{H}$. Hooghoff. Enschede: Dutch National Institute for Curriculum Development (SLO).

Fraenkel, J. R.. A. H. McNaughton, N. E. Wallen, and M. C. Durkin. 1969. Improving elementary-school social studies. The Elementary School Journal, 70(3): 154-63.

Fraenkel. J. R. 1992. Hilda Taba's contributions to social studies education. Social Education, 56(3): 172-78.

Goodlad, J. I. 1966. The changing school curriculum. New York: Fund for the Advancement of Education.

Goodson, I. 1984. Subjects for study: Towards a social history of curriculum. In Defining the curriculum: Histories and ethnographies. London: Falmer Press.

_ April 1992. Studying school subjects. Curriculum Perspectives 12(1): 23-26.

Graham, S. 1993. Interview, Brisbane, Australia. 27 August.

Haas, J. D. 1977. The era of the new social studies. Boulder: ERIC Clearinghouse for Social Studies/Social Science Education Consortium.

Hertzberg, H. W. 1981. Social studies reform 1880-1980. Boulder: Social Studies Education Consortium.

1989. History and progressivism: A century of reform proposals. In Historical literacy: The case for history in American education, edited by P. Gagnon and the Bradley Commission on History in Schools. Boston: Houghton Mifflin.

Hughes, A. 1993. Interview, Brisbane, Australia. 11 November.

Isham, M. M. 1982. Hilda Taba, 1904-1967: Pioneer in social studies curriculum and teaching. Journal of Thought 17(3): $108-24$.

James, G. 1993. Interview, Brisbane, Australia. 23 August.

Jarolimek, J. 1968. Social studies in elementary education. New York: Macmillan.

Lagemann, E. 1983. Looking at gender:
Women's history. In Historical inquiry in education: A research agenda, edited by J. H. Best. Washington, D.C.: American Educational Research Association.

Meesing, A. (1979). Social studies in Thailand. In Teaching social studies in other nations, edited by H. D. Mehlinger and J. Tucker. Washington, D.C.: Bulletin of the National Council for the Social Studies.

Michaelis, J. U. 1968. Social studies for children in a democracy. New York: Prentice Hall.

Nagai, J. (1979). Social studies in Japan. In Teaching social studies in other nations, edited by H. D. Mehlinger and J. L. Tucker. Washington, D.C.: Bulletin of the National Council for the Social Studies.

Onyabe, V. O. (1979). Social studies in Nigeria. In Teaching social studies in other nations, edited by H. D. Mehlinger and J. L. Tucker. Washington, D.C.: Bulletin of the National Council for the Social Studies.

Openshaw, R. (Ed.). 1992. New Zealand social studies: Past, present and future. Palmerston North: Dunmore Press.

Parry, L. J. 1998. Origins and evolution of elementary social studies in Australia. The Social Studies 89(2): 77-84.

Rossi, J. A. 1992. Uniformity, diversity, and the "new social studies." The Social Studies 83(1): $41-45$.

Smith, R., and R. Funnell. December 1981. Primary social studies: A sensitizing study. A study funded by the Research Committee of the Department of Education, University of Queensland, in conjunction with the Association for Independent Policy Studies.

Stuart, P. 1993. Interview, Brisbane, Australia. 18 August.

Taksa, S. 1993. Interview, Brisbane, Australia. 27 August.

Ukpokodu, N., and E. Osunde. 1996 Emerging democracy in Nigeria: A challenge for social studies education. In International trends and developments in social studies-Seminar report on the International Assembly of the National Council for the Social Studies, Chicago, November 1995, edited by J. Bron and $\mathrm{H}$. Hooghoff. Enschede: Dutch National Institute for Curriculum Development (SLO).

Wright, G. 1993. Interview, Brisbane, Australia. 14 September 